\title{
Structural Equation Modelling the Interrelationships between Service Quality, Customer Satisfaction and Behavioural Intention among Maldivians seeking Medical Tourism Services
}

\begin{abstract}
Ahmed Ali Jaleel ${ }^{a^{*}}$, Ali Khatibi ${ }^{\text {b }}$, S. M. Ferdous Azam ${ }^{c},{ }^{\text {a }} \mathrm{PhD}$ Candidate, Post Graduate Centre, Management and Science University, University Drive, Off Persiaran Olahraga, Section 13, 40100, Selangor, Malaysia, ${ }^{\mathrm{b}, \mathrm{c}}$ Graduate School of Management, Management and Science University, University Drive, Off Persiaran Olahraga, Section 13, 40100, Shah Alam, Selangor, Malaysia,

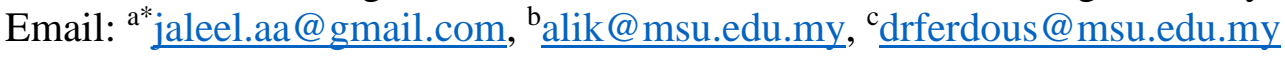

This quantitative study contributes to theory and practice by analysing the interrelationships between service quality, customer satisfaction and behavioural intention among Maldivians' seeking medical tourism services. A total of 385 samples collected using stratified proportionate random sampling and a survey questionnaire approach in a non-contrived cross-sectional setting with minimal interference of the researcher. The study seeks to fill existing gaps in literature related to medical industry, and this study will be a first of its kind for the Maldives, as it is conducted nationwide across the 19 atolls to generalise the results of this study conducted in the Maldives context. The findings indicated that service quality significantly affects customer satisfaction as well as behavioural intention. Further analysis is provided for testing the intervening effect of customer satisfaction on the relationship between service quality and behavioural intention. The study results would help policymakers in the Maldives to formulate better policies on medical care and medical tourism. Academics in the field of business management and marketing would be able to utilise findings to enrich literature. Furthermore, the study assists marketeers and business analysts formulate new marketing strategies to penetrate the South Asian region market, with an emphasis on the medical care industry in the Maldives.

Key words: Behavioural intention, Customer satisfaction, Maldives, Medical care, Medical tourism, Service quality, Structural Equation Modeling (SEM) 


\section{Introduction}

Throughout the years, Maldivians' medical seeking behaviour has changed, an imminent and inevitable continued change especially in the future with the global outbreak of COVID19 in 2020 which has pushed all stakeholders in the medical care industry into uncertain situations. This study is conducted in the Maldives, which comprises of 1192 coral islands with a total forecasted residential population of 533,941, and the Maldives medical care system is structured as a four-tiered referral system, embedded with both public and private support (National Bureau of Statistics - Maldives, 2019).

A report on the Global Healthcare Policy and Management Forum revealed that there are substantial gaps in availability of data for the medical tourism industry (Crooks et al. 2017). Henson, Guy, and Dotson (2015) emphasised that more research needs to be done on the behavioural process of potential or actual medical customers, to find out why they choose to go to specific locations for medical care, how they view medical destinations, and what medical care facilities and service providers they prefer. An observation study carried out by active participation in various events in nine atolls in the Maldives concluded that medical care seekers from scattered communities, especially those in the outer region islands in the Maldives directly travel to capital Male' City instead of going through the 4-tier referral medical care systems (Knoll, 2017). The service quality and public satisfaction, including customer satisfaction and patient satisfaction at the industry level is a critical measure and an indicator of medical and health system quality performance, which is a future research area for the Maldives (Health, Ministry of., 2019). The findings from this empirical study contribute to academics interested in medical care related behaviour, policy makers and managerial stakeholders within the medical care service industry in the Maldives.

\section{Service quality}

Sharma (2017) explains service quality from the viewpoint of medical care, as the art of managing to do the right thing, at the right time, in the right way, for the right person, and with the best possible outcomes. Lee \& Kim (2017) argues that service quality is hard to define as evaluations depend on the type of treatment, experience, and interactions between patients and service providers including characteristics of care services and ethical culture of the medical institution.

The different definitions revealed different conceptualisations in previous studies. The Nordic view led by Gronroos (1984) differentiates service quality on two measurements as utilitarian and specialised quality, whereas the American school view led by Parasuraman, Zeithaml, and Berry (1985) builds the service quality model SERVQUAL with five dimensions to include tangibles, empathy, responsiveness, assurance, and reliability. For the health industry, the MEDQUAL scale was developed by Musa-Juroš et al., (2018) which included three dimensions: trust in the doctor, professionalism, and the organisation of the department, and 
the model resulting drawbacks like low specificity, usable for one single department, and the need to collect data at equal time intervals. Lee (2017) proposed HEALTHQUAL, an integrated model to measure medical and health care service quality, which uses mixed dimensions from the Institute of Medicine, SERVQUAL, a mixed SERVQUAL model, and measurement criteria of international accreditation institutions. Thawornwiriyatrakul and Meeprom (2020) conducted a study on the health and wellness tourism industry in Thailand to conclude that service quality and satisfaction affect customer decision-making and evaluations in selecting a destination.

\section{Customer satisfaction}

Previous literature argues that there is no single universally accepted definition of customer satisfaction among academics. Oliver (2014) describes customer satisfaction as a fulfillment response and as a decision that a product or service feature, or the product or service itself, provided (or is providing) a pleasurable level of fulfillment relevant to consumption. The Nordic School led by Gronroos (1984) claims satisfaction is merely the end-results of the customer perception and the actual quality of the product. The American School of thought led by Parasuraman, Zeithaml, and Berry (1985) considers satisfaction as a positive or negative outcome of a process of comparison between received service and the initial expectation. The Expectation-Disconfirmation Model (Oliver, 1980) indicates that satisfaction is the end-result of the relationship between tourists' expectations they had about a specific destination and their actual experience they had in their destination.

Jawabreh et al., (2020) explains that hospitality is connected to customer satisfaction as business produces and delivers customer satisfaction which is critical for business success. Sudari et al., (2020) found that all elements of the marketing mix which are product, promotion, place and price also has a positive effect on customer satisfaction. Andriano et al., (2019) found that customer satisfaction is a strong predictor of customer loyalty and behavioural intention in the Indonesian restaurant industry.

\section{The relationship between service quality and customer satisfaction}

Contemporary researchers still believe that SERVQUAL and modified SERVQUAL dimensions influence customer satisfaction in medical care organisations (Park et al., 2016). Many authors have conducted studies on the relationship between service quality and customer satisfaction in different contexts and in different industries (Endara et al., 2019; De Bruin et al., 2020). Aljumah et al., (2020) found that service quality affects customer satisfaction among foreigners in Malaysian medical tourism. Endara et al.'s, (2019) research on Libyan banking industry confirmed a positive and significant relationship between service quality and customer satisfaction. De Bruin et al.'s, (2020) study on Islamic banking in South Africa revealed that service quality has a strong positive influence on perceived customer satisfaction. 
Based on debates and discussions in the literature above, this study proposes the following hypothesis:

H1: Service quality has a positive impact on customer satisfaction in medical care in the Maldives

\section{Behavioural intention}

Many researches have been carried to study behavioural intention and its relationships with a number of different variables (Ajzen, 2020; Knoll, 2017; Palmeira et al., 2020). According to the Theory of Planned Behaviour (Ajzen, 1991) used by over 2000 empirical studies (Ajzen, 2020), the attitude towards the behaviour and the perceived control of the behaviour are described as the antecedents of behavioural intention. Behavioural intention has been theorised as loyalty behaviour in terms of repurchase intention, word-of-mouth recommendations, preparedness to pay a premium, and electronic recommendations (Wu et al., 2018).

A positive word-of-mouth (WOM) dimension in behavioural intention improves perceptions whereas a negative WOM conveys mixed cues considering negative WOM and is expected to have a negative impact (Palmeira et al., 2020). Observations on behaviour among Maldivians travelling to seek medical service, revealed that it is unclear why Maldivians in outer area region islands travel directly to capital Male' City instead of going through a series of islands, atolls, and regional levels of referral medical and health care systems (Knoll, 2017). Research on the decision-making process of future or current medical customers was needed to find out why they choose to go to different locations for medical care, how medical destinations are perceived, and what care facilities and service providers they select (Henson, Guy \& Dotson, 2015).

\section{The relationship between service quality and behavioural intention}

Cronin et al., (2000) found that there is a direct relationship between service quality and behavioural intention. Rahman et al. (2018) studied hospitals in Bangladesh to conclude that the performance of the organisation in the service industry was measured by the high degree of customer behavioural intention of use of service consumption, although the understanding, measuring and predicting customer's behavioural intention is challenging for service organisations such as public and private hospitals. Slack and Singh (2020) carried an analysis of Fiji supermarkets to show that service quality significantly affects customer satisfaction, and service quality effects customer loyalty, and customer satisfaction partially mediates the relationship between service quality and customer loyalty. Based on the discussions above, this study proposes the following hypothesis:

$\mathrm{H} 2$ : Service quality has a positive impact on behavioural intention in medical care in the Maldives. 


\section{The relationship between customer satisfaction and behavioural intention}

Customer satisfaction and customer loyalty have been an area of key research interest in service marketing. Many recent studies have been carried out to identify the impact of customer satisfaction on behavioural intention. Slack and Singh's (2020) study in Fiji supermarkets identifies the interrelations between service quality, customer satisfaction and customer loyalty, also that service quality significantly affects customer satisfaction, and service quality effects customer loyalty, and customer satisfaction partially mediates the relationship between service quality and customer loyalty. Aljumah et al., (2020) explains that satisfaction has a significant influence on customer loyalty in Malaysian medical tourism. Calza et al.'s, (2020) research on cruise ship passengers in Italy indicated that the overall customer satisfaction influences behavioural intention significantly. Based on discussions in the literature above, this study proposes the following hypothesis:

H3: Customer satisfaction has a positive impact on behavioural intention in medical care in the Maldives.

\section{The relationship between service quality, customer satisfaction and behavioural intention}

Slack and Singh (2020) conducted a study of Fiji supermarkets and identifies that service quality significantly affects customer satisfaction, and service quality effects customer loyalty, and customer satisfaction partially mediates the relationship between service quality and customer loyalty. Calza et al., (2020) conducted a study in Italy on cruise ships' environment, and find out that all the interrelationships between customer satisfaction, perceived value, and behavioural intention are supported, indicating that the overall customer satisfaction influences behavioural intention significantly. Aljumah et al., (2020) found that satisfaction mediates the relationship between service quality and patient loyalty among foreign patients in Malaysian medical tourism. Although Harazneh et al.'s, (2020) study of Jordanian telecommunications shows a positive and significant impact between service quality and behavioural intention, between customer satisfaction and behavioural intention, between service quality and customer satisfaction, the study also suggested further research in different sectors and countries, especially non-Arabic countries considering various limitations. Based on debates and discussions in the literature provided above, this study proposes the following hypothesis:

H4: Customer satisfaction mediates the relationship between service quality and behavioural intention in medical care in the Maldives.

\section{Conceptual Framework}

This study develops a conceptual framework whose foundation is theorised from three interrelationship models from previous researches which applied service quality, perceived value, customer satisfaction and behavioural intention as variables within the conceptualisation 
(Cronin et al., 2000; Patterson and Spreng, 1997; Oh, 1999), where a study was conducted in the United States of America, and in Australia. The conceptual model of Patterson and Spreng (1997) study which is of an Australian context is one of the few attempts in early research where an attempt was made to explain the dimensions in a business service context. Oh's (1999) study was based on luxury hotels in the USA. Cronin et al.'s (2000) model was on fast food, sporting events and healthcare in the USA. The conceptual model is grounded in three fundamental theories and models: Theory of Planned Behaviour (Ajzen, 1991), ExpectationDisconfirmation-Theory (Oliver, 1980), and the HEALTHQUAL model (Lee, 2017).

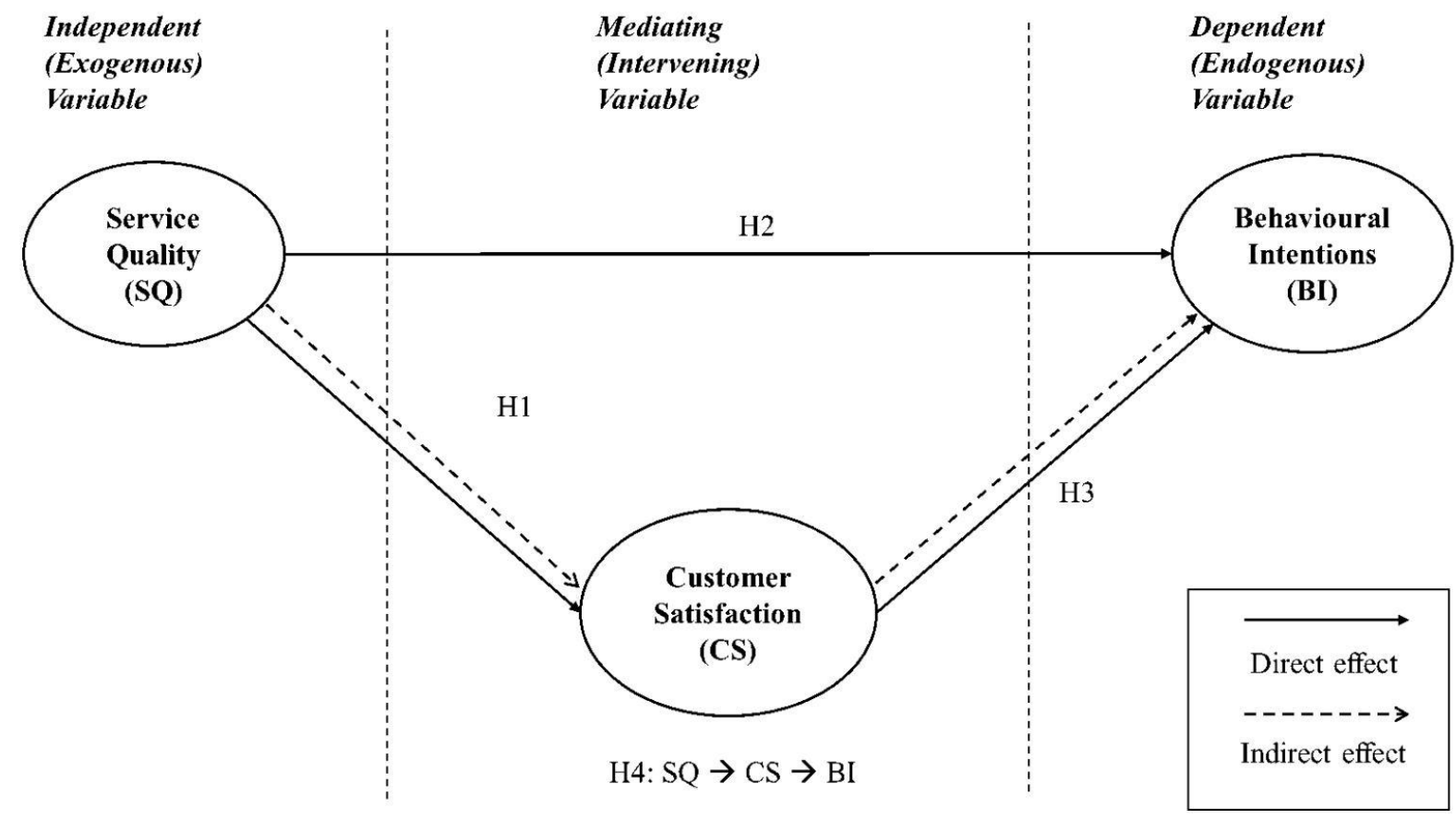

Figure 1: Conceptual framework: Interrelationships between Service Quality, Customer Satisfaction and Behavioural Intention

\section{Research method and data collection}

This section covers survey design, measures, sample frame and sample characteristics, and data analysis tools.

\section{Survey Design}

The survey is cross-sectional, carried in a non-contrived setting where minimum interference of researcher and administrators is involved, and a quantitative research approach is used, which is positivist in nature, and where a survey questionnaire is used. This choice of approach considered as the study facilitates prediction of behaviour from a population that is too large to observe in a direct manner. The data collection took place in 2019 , for a duration of three 
months. This study designed to cover service quality, customer satisfaction, and behavioural intention for the study which is based on available literature.

Section one of this survey included data collection of the respondent's demographic characteristics: gender, age, and residential location, highest level of education completed, occupation, medical care service provider, and number of visits to receive medical care during the last 12 months. Section two comprises of items' scales to capture data related to the service quality, customer satisfaction, and behavioural intention in Maldivians' medical care journey experiences. The Likert scale range from 1-5 where one $(1)=$ strongly disagree, two (2) = disagree, three (3) = neither disagree nor agree, four $(4)=$ agree, and five $(5)=$ strongly agree is used for the study.

\section{Measures for this study}

According to the scales adopted for the study, a quantitative survey questionnaire with 30 items was designed. The service quality related items were adapted from the work of Lee (2017), Chaterjee et al., (2018), and Musa-Juroš et al., (2018). The items for customer satisfaction were adapted from Chaterjee et al., (2018). The items related to behavioural intention adapted from Sharma (2017).

\section{Sampling frame and sample characteristics}

The proportionate stratified random sampling technique is used. A list of respondents who have received medical care and met three conditions were selected: (1) Prior consent and approval to participation voluntarily sought before proceeding collection of responses provided voluntarily; (2) The participant has experienced a medical care journey from the selected service provider for their own self, for a relative or for a dependent, during the last 12 months before the survey period, and (3) The participant is not undergoing any medical treatment that may affect the response feedback. The survey was dispatched to potential respondents in 19 atolls in Maldives, covering a nationwide approach. The respondents have visited medical care institutions registered at the Ministry of Health, Maldives and who fully met criteria above and provided a total sample size of 405 responses during the data collection period of three months.

\section{Data Analysis tools}

The descriptive statistics, reliability test, correlation test, regression test, and exploratory factor analysis using Statistical Package for the Social Sciences (SPSS) software version 23.00. Software Analysis of Moment Structures (AMOS) version 25.00 was used for conducting the confirmatory factor analysis (CFA), and the structural equation model, which include the measurement model and structural model, provides the hypothesis testing of this study. 


\section{Results, discussions and interpretations}

A total of 385 questionnaires were obtained after data cleaning. The main findings below will provide further details on demographic statistics, descriptive statistics, factor loadings, $\mathrm{P}$ values, AVE, CR values, Cronbach's alpha results, confirmatory factor analysis and structural equation modelling.

\section{Main findings}

Table 1 below shows the responding samples' demographic characteristics, and the number of responses with percentage. Table 2, Table 3, and Table 4 provides values of overall mean scores, and standard deviation for the scale items for service quality, customer satisfaction, and behavioural intention respectively.

Table 1: Demographic characteristics of the respondents

\begin{tabular}{lll}
\hline Gender & Number of responses & Percentage $\mathbf{( \% )}$ \\
\hline Male & 178 & 46.2 \\
\hline Female & 207 & 53.8 \\
\hline \hline Age & Number of responses & Percentage $(\boldsymbol{\%})$ \\
\hline Below 20 years & 11 & 2.9 \\
\hline $20-29$ years & 123 & 32.2 \\
\hline $30-39$ years & 132 & 34.3 \\
\hline $40-49$ years & 84 & 21.8 \\
\hline $50-59$ years & 29 & 7.3 \\
\hline Above 60 years & 6 & 1.6 \\
\hline
\end{tabular}

Source: SPSS output. 2020.

Table 1 above reveals that the majority of the respondents are female representation of $53.8 \%$, whereas male representation is $46.2 \%$, indicating a female bias in this study, and the age distribution indicates 20 years to 39 years is found to be a more active group in the population.

Table 2 below provides results for Mean, SD, factor loadings, CR and AVE for variables service quality, customer satisfaction and behavioural intention.

The standard deviation (SD) measures the amount of variability, and provides an indication of how far the individual responses to a question vary or deviate from the mean. The Average Variance Extracted (AVE) value measures the degree of reliability. The Composite Reliability (CR) value measures the convergent validity. The $\alpha$ value measures the internal reliability. 
International Journal of Innovation, Creativity and Change. www.ijicc.net

Volume 15, Issue 3, 2021

Table 2: Descriptive statistics, Standardised Factor Loadings, CR and AVE for service quality, customer satisfaction and behavioural intention

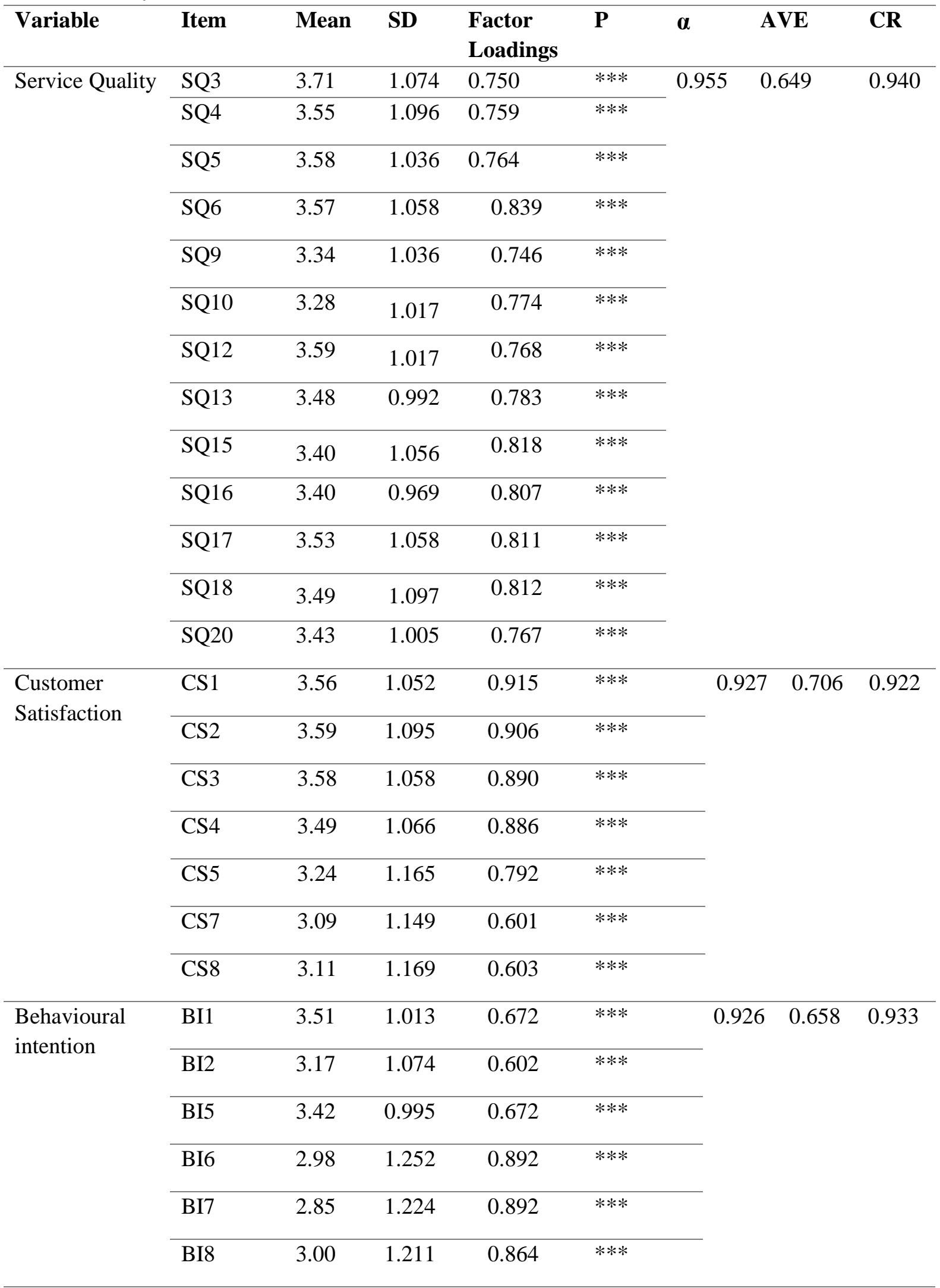


International Journal of Innovation, Creativity and Change. www.ijicc.net

Volume 15, Issue 3, 2021

\begin{tabular}{lllll} 
BI9 & 2.94 & 1.184 & 0.660 & $* * *$ \\
\hline BI13 & 2.94 & 1.228 & 0.678 & $* * *$ \\
\hline BI14 & 2.92 & 1.231 & 0.724 & $* * *$ \\
\hline BI15 & 2.93 & 1.295 & 0.685 & $* * *$
\end{tabular}

Source: SPSS output. 2020.

Table 2 above indicated that mean scores and the standard deviations (SD) for the service quality construct, and the SD for SQ items found to be between 0.969 to 1.132 , and the mean score is between 3.28 and 3.71. The AVE value of 0.649 indicates a satisfactory degree of reliability, whereas the Composite Reliability (CR) value of 0.940 indicates an acceptable measure of convergent validity. The mean scores and the standard deviations for the customer satisfaction (CS) construct, and the SD for CS items were found to be between 1.052 to 1.169. The mean score ranges from 3.09 to 3.59. The mean scores and the standard deviations for the behavioural intention (BI) construct, and the SD for BI items were found to be between 1.127 to 1.466 , where the mean score obtained was between 2.93 and 4.05. The Cronbach's alpha value $(\alpha)$ provides evidence of internal reliability for all the constructs used in this study.

Nunnally (1978) suggested that a coefficient alpha score of 0.70 or above is required to retain an item in a scale. The values of Cronbach's alpha are above 0.9 which is justified as alpha increases are due to the number of items, item correlation, assumptions of alpha (Bandalos, 2018).

\section{Analysis of the mediating effect of customer satisfaction on the relationship between service quality and behavioural intention}

Figure 2 below shows the structural model used to obtain results for the mediation effect of customer satisfaction on the relationship between service quality and behavioural intention. 


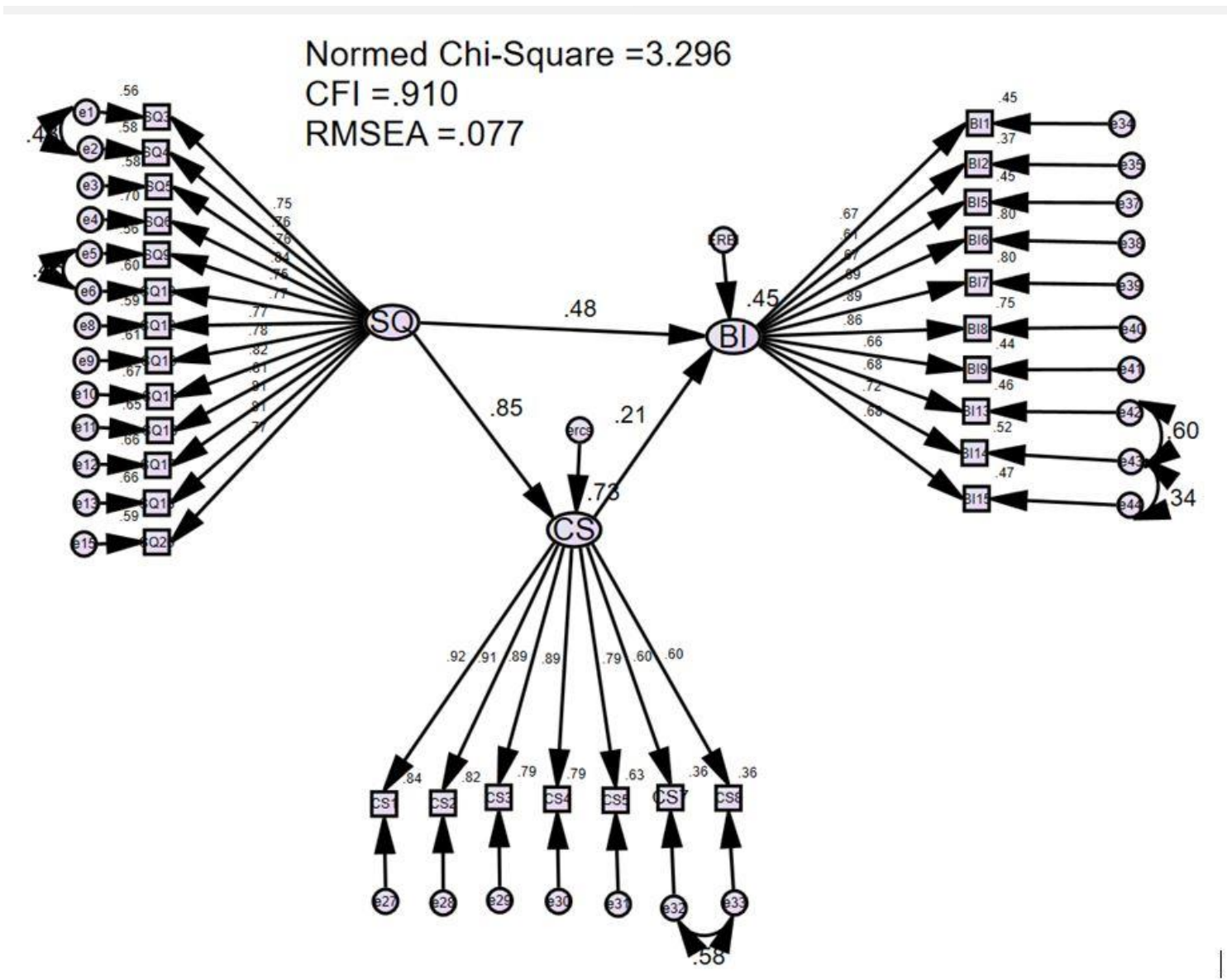

Figure 2. Structural equation model to obtain the measures of mediation by Customer Satisfaction.

The overall fit of the modified structural model from the AMOS output obtained. The results indicate an excellent fit of the structural model.

The fit indexes are tabulated in Table 3 provided below:

Table 3: Fit Index obtained for this study

\begin{tabular}{llll}
\hline & Acceptable fit indices & Study Output & Observation \\
\cline { 1 - 3 } Chi-squared & Dependable on the sample size. & 1308.618 & \\
\cline { 1 - 2 } DF & & $495-98=397$ & \\
\cline { 1 - 3 } P Value & 0.000 & 0.000 & Good fit attained at 5\% \\
\hline Normed & $\begin{array}{l}\text { Between 2.00 and 5.00 is } \\
\text { Chi-Squared }\end{array}$ & 3.296 & \\
& $\begin{array}{l}\text { acceptable. Below 2.0 is very } \\
\text { good (Hair et al., 2019) }\end{array}$ & & \multirow{2}{*}{$\begin{array}{l}\text { Acceptable fit values } \\
\text { attained }\end{array}$} \\
\cline { 1 - 2 } CFI & Above 0.900 (Hair et al., 2019) & 0.910 & \\
\hline RMSEA & Below 0.08 (Hair et al., 2019) & 0.077 &
\end{tabular}

Source: AMOS output. 2020. 
International Journal of Innovation, Creativity and Change. www.ijicc.net

Volume 15, Issue 3, 2021

Table 3 above reveals that the goodness of fit indices Normed Chi-squared value 3.021, degree of freedom of 397 (495-98), P value of 0.000, CFI value of 0.910, and the RMSEA value of 0.077, which is well below the recommended cut-off value of 0.08 (Hair et al., 2019). These results provide sufficient unique information to evaluate this study model.

The results for the regression weights without mediation and with the mediation for the three variables of this study (Service Quality, Customer Satisfaction, and Behavioural Intention) as well as the standardised regression weights checked with and without mediation effect, is tabulated in Table 4 below:

Table 4: The regression weights for the mediating effect of Customer Satisfaction

\begin{tabular}{|c|c|c|c|c|c|}
\hline \multicolumn{5}{|c|}{ Regression Weights without Mediation } & \multirow{2}{*}{$\begin{array}{l}\text { Standardised } \\
\text { Regression } \\
\text { Weights } \\
\text { without } \\
\text { Mediation } \\
\qquad \\
\end{array}$} \\
\hline Relationship & Estimate & S. $E$. & C. $R$. & Pvalue & \\
\hline $\begin{array}{l}\text { Behavioural Intention }(\mathrm{BI}) \leftarrow \text { Service } \\
\text { Quality }\end{array}$ & 0.745 & 0.070 & 10.649 & $* * *$ & 0.659 \\
\hline \multicolumn{4}{|c|}{ Regression Weights with Mediation } & & $\begin{array}{l}\text { Standardised } \\
\text { Regression } \\
\text { Weights with } \\
\text { Mediation }\end{array}$ \\
\hline Relationship & Estimate & S. E. & C. $R$. & $P$ value & Estimate \\
\hline $\begin{array}{l}\text { Behavioural Intention } \leftarrow \text { Service } \\
\text { Quality }\end{array}$ & 0.554 & 0.110 & 5.031 & $* * *$ & 0.481 \\
\hline $\begin{array}{l}\text { Customer Satisfaction } \leftarrow \text { Service } \\
\text { Quality }\end{array}$ & 1.066 & 0.063 & 16.829 & $* * *$ & 0.854 \\
\hline $\begin{array}{l}\text { Behavioural Intention } \leftarrow \text { Customer } \\
\text { Satisfaction }\end{array}$ & 0.192 & 0.083 & 2.303 & 0.021 & 0.201 \\
\hline
\end{tabular}

Source: AMOS output. 2020.

Table 4 above confirms the impact of the mediating variable Customer Satisfaction on the relationship between Service quality and Behavioural Intention. The three stars $(* * *)$ indicates that the p-value is less than 0.01 indicating that the covariance between the construct variable relationships under test is significantly different from 0 at the 0.05 level, and the results of pvalues are below 0.05 which agree in rejecting the null hypotheses for this study. The Critical 
Ratio (C. R.) values for all the three relationships under testing were greater than \pm 1.96 , indicating a significant regression coefficient is achieved. The results above indicate that estimates are positive values, which are significant.

The Sobel test carried next to check the mediating effect of customer satisfaction on the relationship between service quality behavioural intention.

Figure 3 below shows the schematic diagram on the arrangements of the Service QualityCustomer Satisfaction-Behavioural Intention paradigm, and the results obtained from Table 8 above for the respective relationships.

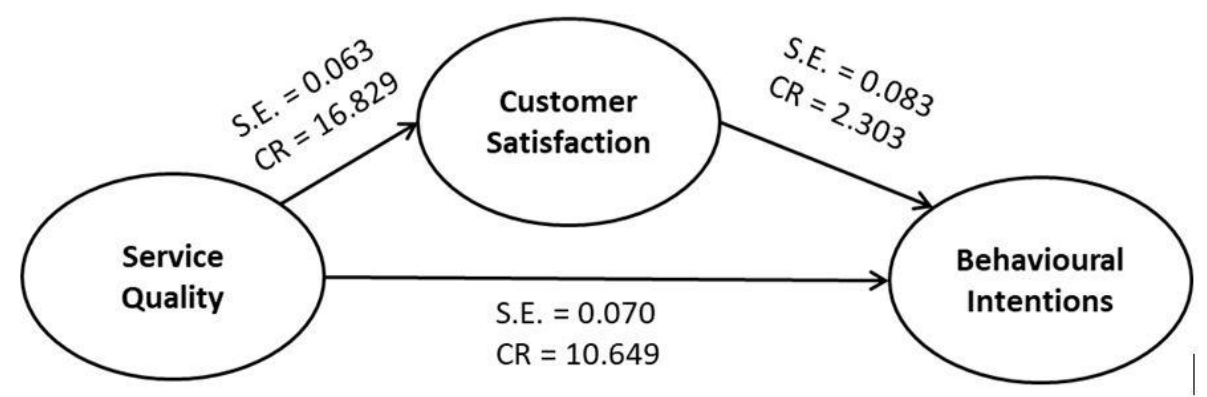

Figure 3: mediation of customer satisfaction on relationship between Service Quality and Behavioral Intention

The results obtained from Table 4 were used for Sobel test using calculation for the Sobel Test on http://quantpsy.org/sobel/sobel.htm , and the results obtained are shown below in Table 5

Table 5: Sobel Test results for mediation of customer satisfaction on the relationship between Service Quality and Behavioral Intention

\begin{tabular}{lll}
\hline & Results & \\
\hline Test & $\begin{array}{l}\text { Statistics } \\
\text { (Z-test) }\end{array}$ & p Value \\
\hline Sobel & 2.28173394 & 0.02250505 \\
\hline Aroian & 2.27778997 & 0.02273909 \\
\hline Goodman & 2.28569846 & 0.02227191 \\
\hline
\end{tabular}

The reported $p$-values are drawn from the unit normal distribution under the assumption of a two-tailed $z$-test of the hypothesis that the mediated effect equals zero in the population. +/1.96 are the critical values of the test ratio which contain the central $95 \%$ of the unit normal distribution. 
The value 2.28173394 from the Z-test, and the p-Value of 0.02250505 indicates that there is a mediating effect of customer satisfaction on the relationship between service quality and behavioural intention.

\section{Hypotheses testing and Results}

This study on medical care among Maldivians seeking medical care within medical tourism services provided empirical evidence and supported all the four hypotheses derived for this study. Table 6 below shows the results for hypotheses testing.

Table 6: Results for hypotheses testing

\begin{tabular}{lll}
\hline $\mathbf{H}(\mathbf{x})$ & Hypotheses & Findings \\
\hline $\mathrm{H} 1$ & $\begin{array}{l}\text { Service quality has a positive impact on customer } \\
\text { satisfaction in medical care in the Maldives. }\end{array}$ & $\begin{array}{l}\text { Supported, based on } \\
\text { Estimate and C. R. results } \\
\text { in Table 4 above }\end{array}$ \\
\cline { 1 - 2 } $\mathrm{H} 2$ & $\begin{array}{l}\text { Service quality has a positive impact on behavioural } \\
\text { intention in medical care in the Maldives. }\end{array}$ \\
\cline { 1 - 2 } $\mathrm{H} 3$ & $\begin{array}{l}\text { Customer satisfaction has a positive impact on } \\
\text { behavioural intention in medical care in the Maldives. }\end{array}$ \\
\hline $\mathrm{H} 4$ & $\begin{array}{l}\text { Customer satisfaction mediates the relationship between } \\
\text { service quality and behavioural intention in medical care } \\
\text { in the Maldives. }\end{array}$ & $\begin{array}{l}\text { Supported by Z-test results } \\
\text { in Table 5 above }\end{array}$ \\
\hline
\end{tabular}

\section{Conclusion}

This study contributes further evidence to interrelationships derived from a conceptual model which considered service quality and customer satisfaction as antecedents to behavioural intention, and the study assesses Maldivians' behavioural intention and its antecedents in seeking medical care within medical tourism services.

This study results confirm that service quality leads positively and significantly to customer satisfaction, which in turn increases behavioural intention in a positive and significant way. The finding is in line with previous studies carried in the Fiji context, the USA context, and the Malaysian context (Slack and Singh, 2020; Cronin et al., 2000; Aljumah et al., 2020). Similarly, service quality and customer satisfaction have been shown to have a significant and direct impact on behavioural intention which is an output in agreement with previous research of De Bruin et al, (2020), and Slack and Singh (2020). The nature of mediation is identified to be a partial mediation, and study findings are in line with the results obtained from previous research work (Aljumah et al., 2020; Cronin et al., 2000; Slack and Singh, 2020) indicating that this study for medical care in Maldives shows a similar pattern to that of health care in the Malaysian medical tourism, healthcare in the USA, and Fiji supermarkets. This study confirms that service quality has both direct and indirect effects on behavioural intention in medical care 
among Maldivians pursuing medical care, indicating agreement with previous researches of Italian cruise ship passengers (Calza et al., 2020), that of the restaurant industry in Indonesia (Andriano et al., 2019), and the telecommunication industry in Jordan (Harazneh et al., 2020).

More significantly, this study is the first of its kind in the sense of behavioural intention of Maldivians seeking medical care,to demonstrate the mediating role of customer satisfaction on the relationship between service quality and behavioural intention, and to generalise the findings in the Maldives context as samples obtained from all the 19 atolls which cover the entire geography in the Maldives. This research enriches the academic literature on medical seeking behaviour in a different context, as this study was conducted with an emphasis on the interrelations between service quality, customer satisfaction and evidencing the value of customer behavioural intention among Maldivians pursuing medical care within medical tourism related services.

\section{Theoretical and managerial implications}

This study enriches the literature on medical care and medical tourism, evidencing the importance of customer behavioural intention in seeking local and overseas medical care from various medical care service providers. The findings from this research will also contribute to the current knowledge gaps identified by the Global Healthcare Policy and Management Forum, and provide contributions to Maldives National Health Research, as studies on service quality, customer satisfaction and behavioural intention are stipulated as future research areas. Although this study will focus on the medical care industry in the Maldives, the information gained about the service quality, perceived values, customer satisfaction and visit or revisit intention generalised at the atoll level, it could be further explored at island level, or to different geographical clusters within Maldives. This study reveals that organisations need to consider that customer-oriented benefits immensely as the customer's view of service quality results in customer satisfaction and customer behavioural intention.

Managers and policy makers need to understand that customers who have a positive view based on the quality of interactions during their service encounters while receiving the service from the specific organisations, result in a higher level of satisfaction, which inadvertently provokes a behavioural intent to revisit or repurchase. This indicates the need for connecting both internal and external customer satisfaction towards improving and developing strategies related to competitive advantages of service quality and customer satisfaction, while action plans based on the study findings may provide additional benefits to service providers and customers in the medical care industry. 


\section{Limitations and directions for future research}

There are limitations in literature as only the English language is selected as a search language option. This study was carried at an atoll level, instead of individual island levels. The approach to data collection considered in this study is a cross-sectional study in a non-contrived environment, as it is possible to change over time, as individuals' perception and beliefs on their experience can easily change. Thus, a longitudinal study in the contexts of individual islands may provide a different set of results in further studies conducted at individual island levels, which may be more time-consuming yet reap further insight on similar studies in the Maldives. 
International Journal of Innovation, Creativity and Change. www.ijicc.net

Volume 15, Issue 3, 2021

\section{REFERENCES}

Aljumah, A., Nuseir, M. T., \& Islam, A. (2020). Impacts of Service Quality, Satisfaction and Trust on the Loyalty of Foreign Patients in Malaysian Medical Tourism. International Journal of Innovation, Creativity and Change, 11(2), 451-467.

Ajzen, I. (2020). The theory of planned behavior: Frequently asked questions. Human Behavior \& Emerging Technology, (2020), 1-11. DOI: 10.1002/hbe2.195.

Ajzen, I. (1991). "The Theory of Planned Behavior". Organizational Behavior and Human Decision Process, 50(2), 179-211.

Andriana, R., Saparso, Fitrio, T., Emmywati, \& Badouddin. (2019). Assessing the Relationship between Corporate Reputation, Customer Satisfaction, Behavioural Intentions and Customer Loyalty. International Journal of Innovation, Creativity and Change, 9(4), 183-199.

Bandalos, D. L. (2018). Measurement Theory and Applications for the Social Sciences. New York: The Guilford Press.

Calza, F., Pagliuca, M., Risitano, M., \& Sorrentino, A. (2020). Testimg moderating effects on the relationship among on-board cruise environment, satisfaction, perceived value and behavioral intentions. International Journal of Contemporary Hospitality Management, 32(2), 934-954.

Cronin, J. J., Brady, M. K., \& Hult, G. T. M. (2000). Assessing the effects of quality, value, and customer satisfaction on consumer behavioral intentions in service environments. Journal of Retailing, 76(2), 193-218.

Crooks, V. A., Ormond, M., \& Jin, K. N. (2017). Reflections on 'medical tourism' from the 2016 Global Healthcare Policy and Management Forum. BMC Proceedings, 11(Suppl 8), 6. https://doi.org/10.1186/s12919-017-0075-8

De Bruin, L., Roberts-Lombard, M., \& De Meyer-Heydenrych, C. (2020). Internal marketing, service quality and perceived customer satisfaction: An Islamic banking perspective. Journal of Islamic Marketing, Vol. ahead-of-print No. Ahead-of-print, https://doi.org/10.1108/JIMA-09-2019-0185.

Duhachek, A., Coughlan, A. T., \& Iacobucci, D. (2005). Results on the Standard Error of the Coefficient Alpha Index of Reliability. Marketing Science, 24(2), 294-301.

Endara, Y. M., Ali, A. B., \& Yajid, M. S. (2019). The influence of culture on service quality leading to customer satisfaction and moderation role of type of bank, Journal of Islamic Accounting and Business Research, 10(1), 134-154.

Gronroos, C. (1984). A service quality model and its marketing implications. European Journal of Marketing. 18(4), 36-44.

Hair, J. F., Black, W. C., Anderson, R. E., \& Babib, B. J. (2019). Multivariate data analysis ( $8^{\text {th }}$ ed.). London: Cengage Learning.

Harazneh, I., Adaileh, M. J., Thbeitat, A., Afaneh, S., Khanfar, S., Harasis, A. A., \& Elrehail, H. (2020). The impact of quality of service and satisfaction on customer loyalty: The moderate role of switching costs. Management Science Letters, 10(2020), 1843-1856. 
International Journal of Innovation, Creativity and Change. www.ijicc.net

Volume 15, Issue 3, 2021

Health, Ministry of. (2019). Maldives Health Research Bulletin, Vol. VI, Health, M. O. (ed.): Maldives. Retrieved from http://www.health.gov.mv/Uploads/Downloads//Publications/Publication(61).pdf

Henson, J. N., Guy, B. S., \& Dotson, M. J. (2015). Should I stay or should I go?: Motivators, decision factors, and information source influencing those predisposed to medical tourism. International Journal of Healthcare Management, 8(1): 4-14.

Jawabreh, O. A., Jahmani, A., Khaleefa, Q. Q., Alshatnawi, E. A. R., \& Abdelrazaq, H. (2020). Customer Expectation in Five Star Hotels in Aquaba Special Economic Zone Authority (ASEZA). International Journal of Innovation, Creativity and Change, 11(4), 417-438.

Knoll, E. (2017). Archipelagic genes: Medical travel as a creative response to limitations and remoteness in the Maldives. Asia Pacific Viewpoint, 58(20), 48-161.

Krejcie, R. V. \& Morgan, D. W. (1970). Determining sample size for research activities. Educational and Psychological Measurements, 30(1), 607-610.

Lari, L., Jabeen, F. \& Iyanna, S. (2020). Prioritising theme park service quality in Islamic contexts: an analytic hierarchy process approach. International Journal of Culture, tourism and Hospitality Research, Vol. ahead-of-print no. ahead-of-print. Https://doi.org/10.1108/IJCTHR-10-2018-0147.

Lee (2017). HEALTHQUAL: a multi-item scale for assessing healthcare service quality, Service Business - An International Journal, 11(3). 491-516.

Lee, D. \& Kim, K. K. (2017). Assessing healthcare service quality: a comparative study of patient treatment types. International Journal of Quality Innovation; ISSN 2363-7021, Springer, Heidelberg, 3(1), 1-15.

Maldives Health Research Bulletin (2019). Vol. VI, Health, M. O. (ed.): The Maldives. Retrieved from http://health.gov.mv/Uploads/Downloads//Publications/Publication(61).pdf

Musa-Juroš, K., Mijoč, J., Horvat, J., Ilakovac, V., Marković, S., \& Racz, A. (2018). Measuring Healthcare Quality - Paradigm of Medqual. Acta clinica Croatica, 57(2), 235-242. https://doi.org/10.20471/acc.2018.57.02.02

National Bureau of Statistics - Maldives. (2019). Maldives in figures - May 2019, National Bureau of Statistics Maldives. Retrieved from http://statisticsmaldives.gov.mv/maldivesin-figures-may-2019/

Nunnally, J. C. (1978). Psychometric theory. 2nd Edition, McGraw-Hill, New York.

Oh, H. (1999). Service quality, customer satisfaction, and customer value: A holistic perspective. International Journal of Hospitality Management, (1999), 18(1), 67-82.

Oliver, R. L. (1980). A cognitive model of antecedents and consequences of satisfaction decisions. Journal of Marketing Research, 17(4), 460-469.

Oliver, R. L. (2014). Satisfaction: A Behavioral Perspective on the Consumer, Routledge: New York, NY.

Palmeira, M., Spassova, G., \& Quoidbach, J. (2020). You're not yelping your case: the unexpected social consequences of word of mouth. European Journal of Marketing, 54(2), 419-447. 
International Journal of Innovation, Creativity and Change. www.ijicc.net

Volume 15, Issue 3, 2021

Parasuraman, A., Zeithaml, V. A., \& Berry, L. L. (1985). A conceptual model of service quality and its implication for future research. Journal of Marketing, 49(4), 10-16.

Park, G. W., Kim, Y., Park, K. \& Agarwal, A. (2016). Patient-centric quality assessment framework for healthcare services. Technological Forecasting and Social Change. 113(1), 468-774.

Patterson, P. G., \& Spreng, R. A. (1997). Modelling the relationship between perceived value, satisfaction and repurchase intentions in a business-to-business, services context: an empirical examination. International Journal of Service Industry Management, 8(5), 414-434.

Rahman, M. S., Mannan, M., Hossain, M. A., \& Zaman, M. H. (2018). Patient's behavioral intentions: public and private hospitals context. Marketing Intelligence \& Planning, 36(3), 349-364. https://doi.org/10.1108/MIP-08-2017-0155.

Sharma, V. (2017). Patient satisfaction and brand loyalty in healthcare organizations in India. Journal of Asia Business Studies, 11(1), 73-87. https://doi.org/10.1108/JABS-09-2015$\underline{0157}$

Slack, N. J. \& Singh, G. (2020). The effect of service quality on customer satisfaction and loyalty and the mediating role of customer satisfaction: Supermarkets in Fiji. The TQM Journal, DOI: 10.1108/TQM-07-2019-0187.

Thawornwiriyatraku, W. \& Meeprom, S. (2020). Antecedents of Tourist Loyalty in Health and Wellness Tourism: The Impact of Travel Motives, Perceived Service Quality, and Satisfaction. International Journal of Innovation, Creativity and Change, 11(10), 300315.

Wong, K. H., Chang, H. H., \& Yeh, C. H. (2019). The effect of consumption values and relational benefits on smartphone brand switching behavior. Information Technology \& People, 32(1), 217-243.

Wu, H., Cheng, C., \& Ai, C. (2018). A study of experiential quality, experiential value, trust, corporate reputation, experiential satisfaction and behavioral intentions for cruise tourists: The case of Hong Kong. Tourism Management, 66(1), 200-220.

Zaid, M., Jutatip, S., \& Keiwkarnka, B. (2013). Patient satisfaction towards the service quality of outpatient department of Indira Gandi Memorial Hospital in Maldives. Journal of Health Research, 27(5), 339-344. 